\title{
Differential and Time-Dependent Changes in Gene Expression for Type II Calcium/Calmodulin-Dependent Protein Kinase, 67 kDa Glutamic Acid Decarboxylase, and Glutamate Receptor Subunits in Tetanus Toxin-Induced Focal Epilepsy
}

\author{
Fengyi Liang and Edward G. Jones \\ Department of Anatomy and Neurobiology, University of California, Irvine, California 92697
}

\begin{abstract}
To study potential molecular mechanisms of epileptogenesis in the neocortex, the motor cortex of rats was injected with tetanus toxin (TT), and gene expression for $67 \mathrm{kDa}$ glutamic acid decarboxylase (GAD-67), type II calcium/calmodulindependent protein kinase (CaMKII), NMDA receptor subunit 1 (NR1), and AMPA receptor subunit 2 (GluR2) was investigated by in situ hybridization histochemistry. Injections of 20-35 ng TT induced recurrent seizures after a postoperative period ranging from 4 to $13 \mathrm{~d}$. A majority of rats perfused 5-7 d after TT injection showed altered gene expression, but the changes varied in their areal extent, ranging from most neocortical areas on the injected side in some rats to mainly the frontoparietal cortex or the motor cortex in others. Epileptic rats perfused $14 \mathrm{~d}$ after $T \mathrm{~T}$ injection showed a focus of increased GAD-67 and NR1, and of decreased $\alpha$-CaMKII and GluR2 mRNA levels
\end{abstract}

at the injection site. A zone of cortex surrounding the focus showed changes in $\alpha$-CaMKII, GAD-67, and NR1 mRNA levels that were reciprocal to those in the focus. The results suggest that TT-induced seizure activity initially spread to a variable extent but was gradually restricted 2-3 d after seizure onset. The focus and the surround showing reciprocal changes in gene expression are thought to correspond to the electrophysiologically identified epileptic focus and inhibitory surround, respectively. The findings suggest that lateral inhibition between neighboring cortical regions will be affected and contribute to a neurochemical segregation of an epileptic focus from surrounding cortex.

Key words: epilepsy; motor cortex; rat; NMDA receptor; AMPA; $\gamma$-aminobutyric acid; protein kinase; inhibition
Epileptic seizures are clinical manifestations of abnormally hyperactive and/or hypersynchronous neuronal discharges in cerebral cortex and certain subcortical regions. Neural mechanisms underlying generation and persistence of epilepsy may involve changes in neuronal excitability resulting from an imbalance between excitation and inhibition. Disturbances of GABAergic and/or glutamatergic transmission are especially implicated (Prince et al., 1992; Meldrum, 1994; Lopes da Silva et al., 1995). Activitydependent changes in gene expression for molecules involved in GABAergic and glutamatergic neurotransmission may maintain long-term neuronal hyperexcitability and hyperactivity in epilepsy; however, reports of altered gene expression in epilepsy are inconsistent. Immunoreactivity, mRNA levels, and/or receptor binding for glutamic acid decarboxylase (GAD), NMDA receptor and/or AMPA receptor subunits have been reported to be increased (Feldblum et al., 1990; Najlerahim et al., 1992; Pollard et al., 1993; Kamphuis et al., 1994; Kraus et al., 1994; Marianowski et al., 1995), unchanged (Lerner-Natoli et al., 1985; Akiyama et al.,

\footnotetext{
Received Oct. 21, 1996; accepted Dec. 20, 1996.

This work was supported by Grant NS21377 from National Institutes of Health, United States Public Health Service. We thank Drs. N. Sucher, J. Boulter, and P. J. Isackson for providing the NR1, GluR2, and CaM kinase II $\beta$ cDNAs, and Drs. M. M. Huntsman and S. Akbarian for help in preparing the cRNA probes. We are also grateful to Mr. C. R. King III, Mr. P. L. Nguyen, Mr. L. D. Le, and Ms. H. N. Truong for expert technical assistance.

Correspondence should be addressed to Dr. E. G. Jones, Department of Anatomy and Neurobiology, University of California, Irvine, CA 92697-1280.

Dr. Liang's present address: Neural Systems Laboratory, Frontier Research Program in Brain Mechanisms of Mind and Behavior, The Institute for Physical and Chemical Research (RIKEN), Wako, Saitama 351-01, Japan.

Copyright (C) 1997 Society for Neuroscience $0270-6474 / 97 / 172168-13 \$ 05.00 / 0$
}

1992; Friedman et al., 1994; Gerfen-Moser et al., 1995), or decreased (Ribak et al., 1979; Gall et al., 1990; Akiyama et al., 1992; Mitsuyoshi et al., 1993; Obenaus et al., 1993; DeFelipe et al., 1994; Friedman et al., 1994; Lee et al., 1994; Bayer et al., 1995; Prince et al., 1995). Discrepancies may have resulted from the experimental models used. Seizure-induced nonspecific pathological changes, such as surgical lesion, hypoxia, stress, and cell degeneration may also induce alterations in gene expression that may be difficult to separate from effects of hyperactivity. Earlier studies on changes in gene expression associated with epilepsy have focused on the limbic system. Potential changes after epileptic activity of other cerebral cortical areas, especially the sensorimotor cortex, remain unknown.

Tetanus toxin (TT) injected in nanogram quantities into brain can induce epileptiform activity by blocking neurotransmitter release (Brooks and Asanuma, 1962; Carrea and Lanari, 1962; Mellanby et al., 1977; Schiavo et al., 1992). It has high selectivity for inhibitory synapses (Collingridge et al., 1981; Bergey et al., 1987; Williamson et al., 1992). Although TT is cleared from brain in 2-4 weeks, epileptiform activity persists for months and may become permanent (Jefferys et al., 1995). The chronic recurrent epilepsy that is induced resembles clinical epilepsy in humans. It causes no apparent cell loss (Kessler and Markowitsch, 1983; Jefferys et al., 1992) and requires little manipulation of animals after TT injection so that nonspecific effects, e.g., stress and anesthesia, can be avoided. Electrophysiological studies have been conducted on this model of epilepsy (Mellanby et al., 1977; Brener et al., 1990; Louis et al., 1990; Najlerahim et al., 1992; Empson et al., 1993), but relatively little is known at cellular and 
molecular levels. Upregulation of GAD mRNA levels or transient impairment of GABA release has been reported in rats after TT injection in hippocampus or parietal cortex (Najlerahim et al., 1992; Empson et al., 1993).

We examined gene expression for molecules involved in GABAergic and glutamatergic transmission in neocortex, namely type II $\mathrm{Ca}^{2+} /$ calmodulin-dependent protein kinase (CaMKII), GAD, and the most highly expressed NMDA and AMPA receptor subunits, in the presence of focal epilepsy induced by TT injection.

Preliminary results have been published previously (Liang and Jones, 1994, 1996a).

\section{MATERIALS AND METHODS}

Surgery and TT injection. In pilot experiments, $19 \mathrm{Wistar}$ rats of either sex and weighing 180-310 gm were injected with 2-13 ng TT in the motor cortex and perfused under deep anesthesia 1-28 d later. None showed clear evidence of seizures, and only two showed localized changes in gene expression (CaMKII $\alpha)$ at the injection site (see Results). Subsequently, therefore, injections in excess of $13 \mathrm{ng}$ TT were used. The higher dosage for inducing seizures in the motor cortex in comparison with hippocampus and parietal cortex (Brener et al., 1990; Francis et al., 1990) is consistent with other investigations (Mellanby et al., 1977).

In the final experiments, 34 Wistar rats of either sex and weighing 150-290 gm were used. Twenty-four rats were injected with TT (1 with 20 ng, 16 each with $25 \mathrm{ng}$, and 7 each with $35 \mathrm{ng}$ ). Eight controls were injected with $0.8 \mu \mathrm{l} 0.9 \% \mathrm{NaCl}$. Except for two rats perfused on postoperative day 7, all TT-injected rats in the final experiments had seizures (see Results). Seven of the TT-injected rats (three with $35 \mathrm{ng}$ TT, three with $25 \mathrm{ng}$ TT, and one with $20 \mathrm{ng}$ TT) died of generalized seizures on postoperative days 4-11 and were excluded from further analysis. Four of the rats (two injected with $35 \mathrm{ng}$ and two with $25 \mathrm{ng}$ TT) had severe, generalized, seizure activity and were perfused on postoperative day 5 . The remaining 13 TT-injected rats had less severe, focal, or intermittent seizures. Six were perfused on postoperative day 7 and the other seven on postoperative day 14 . The saline-injected control rats were perfused on postoperative day $5(n=2), 7(n=3)$, or $14(n=3)$. Two normal control rats were perfused under nembutal anesthesia without any previous surgical operation.

For injection of TT in the motor cortex, the rats were anesthetized with ketamine $(100-150 \mathrm{mg} / \mathrm{kg}$ body weight, i.m., plus $25 \mathrm{mg} / \mathrm{kg}$ additional doses when necessary). The skull was opened on one side. The opening was centered at $1.0 \mathrm{~mm}$ rostral to bregma, $2.7-3.0 \mathrm{~mm}$ lateral to the midline, and had a diameter of $\sim 1.5 \mathrm{~mm}$. The dura mater was left intact. The representation of digit/wrist movements in the motor cortex was identified by intracortical microstimulation (ICMS); $30 \mathrm{msec}$ trains consisting of cathodal pulses of $0.2 \mathrm{msec}$ width and $300 / \mathrm{sec}$ rate were given (Asanuma and Sakata, 1967), using a low-impedance $(<1 \mathrm{M} \Omega$ at $1 \mathrm{KHz})$ tungsten microelectrode inserted through the dura mater into the cortex 1.6-1.7 $\mathrm{mm}$ below the dural surface. The electrode was first positioned according to published motor maps (Hall and Lindholm, 1974; Neafsey et al., 1986), and, if necessary, was moved to find a locus from which clear movements of the contralateral wrist and/or digits could be elicited by low-threshold ICMS $(<30 \mu \mathrm{A})$. This locus was almost invariably located $0.8-1.1 \mathrm{~mm}$ rostral to bregma, 2.7-3.0 $\mathrm{mm}$ lateral to the midline, and 1.6-1.8 mm deep from the dural surface. TT (List Biologicals, Campbell, CA) diluted in $0.3-0.8 \mu 10.9 \% \mathrm{NaCl}$ was injected at the above ICMS site at a depth of $1.2 \mathrm{~mm}$ from the dural surface. The glass micropipettes used for TT injection had external tip diameters of 20-30 $\mu \mathrm{m}$.

The animals were monitored daily after the injection for epileptic behavior. They were anesthetized finally with nembutal $(80 \mathrm{mg} / \mathrm{kg})$ and perfused transcardially with saline followed by $4 \%$ paraformaldehyde in $0.1 \mathrm{M}$ phosphate buffer. The brains were removed, post-fixed at $4^{\circ} \mathrm{C}$ in the same fixative for 3-6 hr, and cryoprotected with $30 \%$ sucrose. Frozen sections $40 \mu \mathrm{m}$ thick were cut on a sliding microtome, and sections were collected in $0.1 \mathrm{M}$ phosphate-buffered $4 \%$ paraformaldehyde, $\mathrm{pH} 7.4$, for in situ hybridization histochemistry.

In situ hybridization histochemistry. The detailed protocol for in situ hybridization histochemistry has been reported in detail elsewhere (Benson et al., 1991a,b). Free-floating sections were rinsed twice in $0.1 \mathrm{M}$ phosphate-buffered glycine $(0.75 \%, \mathrm{pH} 7.4)$ followed by a wash in $0.1 \mathrm{M}$ phosphate buffer, $\mathrm{pH}$ 7.4. They were then digested with proteinase $\mathrm{K}(0.5$ $\mu \mathrm{g} / \mathrm{ml} 0.1 \mathrm{M}$ Tris- $\mathrm{HCl}$ buffer, $\mathrm{pH}$ 8.0, containing 0.05 м EDTA) for 8-10 $\mathrm{min}$ at room temperature. Digestion was stopped with $0.25 \%$ acetic anhydride in $0.1 \mathrm{M}$ triethanolamine, $\mathrm{pH}$ 8.0. After two washes in $2 \times \mathrm{SSC}$ (saline/sodium citrate, $\mathrm{pH} 7.0 ; 1 \times \mathrm{SSC}$ consists of $0.88 \% \mathrm{NaCl}$ and $0.44 \%$ $\mathrm{Na}_{3} \mathrm{C}_{6} \mathrm{H}_{5} \mathrm{O}_{7} \cdot 2 \mathrm{H}_{2} \mathrm{O}$ ), the sections were incubated for $1 \mathrm{hr}$ at $60^{\circ} \mathrm{C}$ in hybridization buffer consisting of $50 \%$ deionized formamide, $10 \%$ dextran sulfate, $5 \% 2 \times$ SSC, $0.9 \%$ Ficoll, $0.9 \%$ polyvinyl pyrolidone, and $0.9 \%$ bovine serum albumin. Just before use, $0.3 \mathrm{mg} / \mathrm{ml}$ of herring sperm DNA, $0.15 \mathrm{mg} / \mathrm{ml}$ of wheat germ transfer RNA, and $40 \mathrm{~mm} / \mathrm{ml}$ of dithiothreitol (DTT) were added. Sections were then transferred to new hybridization buffer containing one of the following cRNA probes.

CaMKII $\alpha$ riboprobes were transcribed from a cDNA encoding a part of monkey CaMKII $\alpha$ that corresponds to bases $869-1185$ of the rat CaMKII $\alpha$ gene. It also contained a 33 base insert $(\alpha-33)$ beginning at nucleotide 984 of the rat sequence (Benson et al., 1991a). Antisense riboprobes made from this cDNA recognize both CaMKII $\alpha$ and $\alpha-33$ mRNAs but do not recognize mRNAs for other subunits of the kinase. Riboprobes for the $\beta$ subunit of CaMKII $(\mathrm{CaMKII} \beta)$ were transcribed from a cDNA encoding a part of human CaMKII $\beta$ that corresponds to bases $550-1320$ of the rat CaMKII $\beta$ gene. Antisense riboprobes made from this cDNA recognize both CaMKII $\beta$ and $\beta^{\prime}$ subunit mRNAs but do not recognize mRNAs for the $\alpha$ or $\alpha-33$ subunits of the kinase; $67 \mathrm{kDa}$ GAD (GAD-67) riboprobes were transcribed from a 360 base (bases 1324-1683) nucleotide, monkey cDNA encoding a part of GAD-67 (Benson et al., 1991a). cRNA probes for NMDA receptor subunit 1 (NR1) were transcribed from a 2700 base nucleotide encoding rat NR1 splicing variant C (Sugihara et al., 1992). It is $93-100 \%$ complementary to other splice variants of the NR1 subunit. cRNA probes for AMPA-type glutamate receptor subunit 2 (GluR2) were transcribed from a nucleotide encoding a part of human GluR2 that corresponds to bases 1581-1952 of rat GluR2 (Boulter et al., 1990; Keinänen et al., 1990). All nucleotides were cloned into the $\mathrm{pBKS}(+)$ BlueScript vector and were linearized before transcription labeling of the sense or antisense riboprobes with ${ }^{35}$ S- or ${ }^{33} \mathrm{P}-\mathrm{UTP}$.

Preliminary tests showed that all of the antisense probes gave specific labeling patterns in the CNS of the rat similar to those described previously in the monkey (Benson et al., 1991b; Jones et al., 1994), cat (Liang and Jones, 1996b), rat (Benson et al., 1992; Liang et al., 1996), or human (Akbarian et al., 1996). All probes were diluted to a final concentration of $1.0-1.5 \times 10^{7} \mathrm{cpm} / \mathrm{ml}$ hybridization buffer. They had similar $\mathrm{G} / \mathrm{C}$ ratios and similar specific activities.

After $20-36 \mathrm{hr}$ incubation at $60^{\circ} \mathrm{C}$, the sections were washed sequentially in the following solutions (except for ribonuclease A, all contained $5 \mathrm{~mm} \mathrm{DTT} / \mathrm{ml}): 4 \times \mathrm{SSC}, 60^{\circ} \mathrm{C}$, twice, $20 \mathrm{~min}$ each; ribonuclease A $(0.02$ $\mathrm{mg} / \mathrm{ml}$ in $0.01 \mathrm{M}$ Tris- $\mathrm{HCl}$ buffer, $\mathrm{pH} 8.0$, and $1 \mathrm{~mm}$ EDTA, $2.9 \% \mathrm{NaCl}$ ) at $45^{\circ} \mathrm{C}, 30 \mathrm{~min} ; 2 \times \mathrm{SSC}$, room temperature, twice, $30 \mathrm{~min}$ each; $0.5 \times$ $\mathrm{SSC}, 60^{\circ} \mathrm{C}$, twice, $30 \mathrm{~min}$ each; $0.1 \times \mathrm{SSC}$, room temperature, twice, 20 min each. Sections were then mounted on chrome alum-gelatin-coated glass slides, air-dried, placed in contact with Amersham $\beta$-Max film (Amersham, Arlington Heights, IL), and exposed for 1-6 d. All sections for in situ hybridization from both sides of the brain of individual rats were hybridized simultaneously and exposed on the same sheet of film. After development of the film, the slides were dipped in Kodak NTB2 emulsion and exposed at $4^{\circ} \mathrm{C}$ for $4-8$ weeks. Autoradiograms were then developed in Kodak D-19, counterstained with cresyl violet, dehydrated in graded alcohols, cleared in xylene, and coverslipped in DPX.

One of every 24 sections was used as a control by hybridizing with sense riboprobes. No hybridization above background levels was found. In each animal, a series of sections was also mounted and stained with thionin.

Data analysis. Sections labeled by in situ hybridization histochemistry were examined for differences between the ipsi- and contralateral hemispheres and between different cortical and subcortical regions in individual rats. Differences were then compared across animals. Optical density measurements were made of autoradiograms, using a computer-assisted image analysis system (MCID, Imaging Research, St. Catharine's, Ontario, Canada). The relative optical density (ROD) was defined on an 8 bit black/white video image with gray level 255 (white) as 0.0017 ROD (no hybridization signal) and gray level 0 (black) as 2.4082 ROD (highest hybridization signal). The ROD values were converted to measures of radioactivity (microcuries/gram) by reference to a set of ${ }^{14} \mathrm{C}$ standards (Amersham) exposed on the same sheet of film and then compared between the two hemispheres and across cortical areas.

For quantitative analysis of changes in gene expression across different cortical areas, sampling was made in rectangles measuring 0.042-0.047 $\mathrm{mm}^{2}$ from cortical areas that showed potential changes in gene expres- 
sion, and from homotopic cortical areas on the contralateral side. For each cortical area of each animal, 12-16 samples from two to three sections were collected. Background radioactivity was determined for each section by averaging six samples from the underlying white matter. Background was subtracted from all readings from all cortical areas before a mean value of radioactivity for each cortical area of individual animals was calculated. Student's paired $t$ test was performed to assess the significance of differences in gene expression in homotopic areas on the two sides for each control and experimental animal group. A percentage change in gene expression for a cortical area was then generated by dividing the mean radioactivity reading from the ipsilateral side by the mean reading from the corresponding cortical area on the contralateral side. A grand mean of percentage change for each mRNA probe was then computed by averaging means from individual animals from the same TT dosage or survival group.

In measuring changes in different cortical areas the homotopic area on the contralateral side was used as a control. This was based on our observation that cortical areas on the side contralateral to TT injection, in most cases, did not show obvious differences in the patterns of gene expression from saline-injected or normal controls, with the exception of a few animals in which the contralateral motor cortex showed slight changes in GAD and possibly NR1 gene expression. For these probes, therefore, quantitative comparison between motor cortical areas on the two sides was supplemented by comparing values from the injected motor cortex with those from the first somatosensory area on the contralateral side, which showed no detectable change in gene expression in any of the animals.

\section{RESULTS}

\section{TT dose-dependent seizure development}

Of the 19 rats injected with $2-13 \mathrm{ng}$ TT in the pilot experiments, none showed clear evidence of seizures up to postoperative day 28. Of the other 24 rats injected with 20-35 ng TT, 22 showed seizure activity. The earliest observed signs of seizure started on day 4 and the latest on day 13 after the injection. The most frequently observed signs of focal seizure consisted of transient repetitive flicking movements of the contralateral forelimb, accompanied by hiccup-like respiration. Once commenced, seizure activity tended to be more severe in the first 2-3 d after onset. Only one rat was observed having a stage 5 seizure (rearing and falling; Racine, 1972). None of the control rats showed signs of seizure activity.

For all TT-injected rats, no observable cell loss or clear changes in the general histological organization of cortical layers at the injection site were seen, as compared with the contralateral motor cortex or with that in control rats (Fig. 1).

\section{CaMKII $\alpha$ in situ hybridization}

\section{Normal pattern of hybridization}

CaMKII $\alpha$ mRNA distribution in normal rat brain has been described previously (Benson et al., 1992; Liang et al., 1996). mRNA levels for CaMKII $\alpha$ were high in the hippocampus and the cerebral cortex and intermediate in the striatum, septum, and thalamus. In the neocortex, mRNA levels were high in layers II-IV, intermediate in layer VI, and moderate in layers I and V (Figs. 2A, 3A).

\section{Time-dependent down- and upregulation at the TT injection site and in the surround}

Most of the rats that were injected with 2-13 ng TT in the pilot experiments did not show significant changes in CaMKII $\alpha$ mRNA levels in any regions of the forebrain. Two rats that received 3 and $4.5 \mathrm{ng}$ TT and survived for $28 \mathrm{~d}$ after the injection had very localized downregulation of CaMKII $\alpha$ mRNA levels at the injection site in an area extending mediolaterally for $0.75-0.80 \mathrm{~mm}$. Mainly layers III-V were affected (Fig. 3B).

In the final experiments, rats perfused $5 \mathrm{~d}$ after larger TT injections showed results similar to those that were perfused after

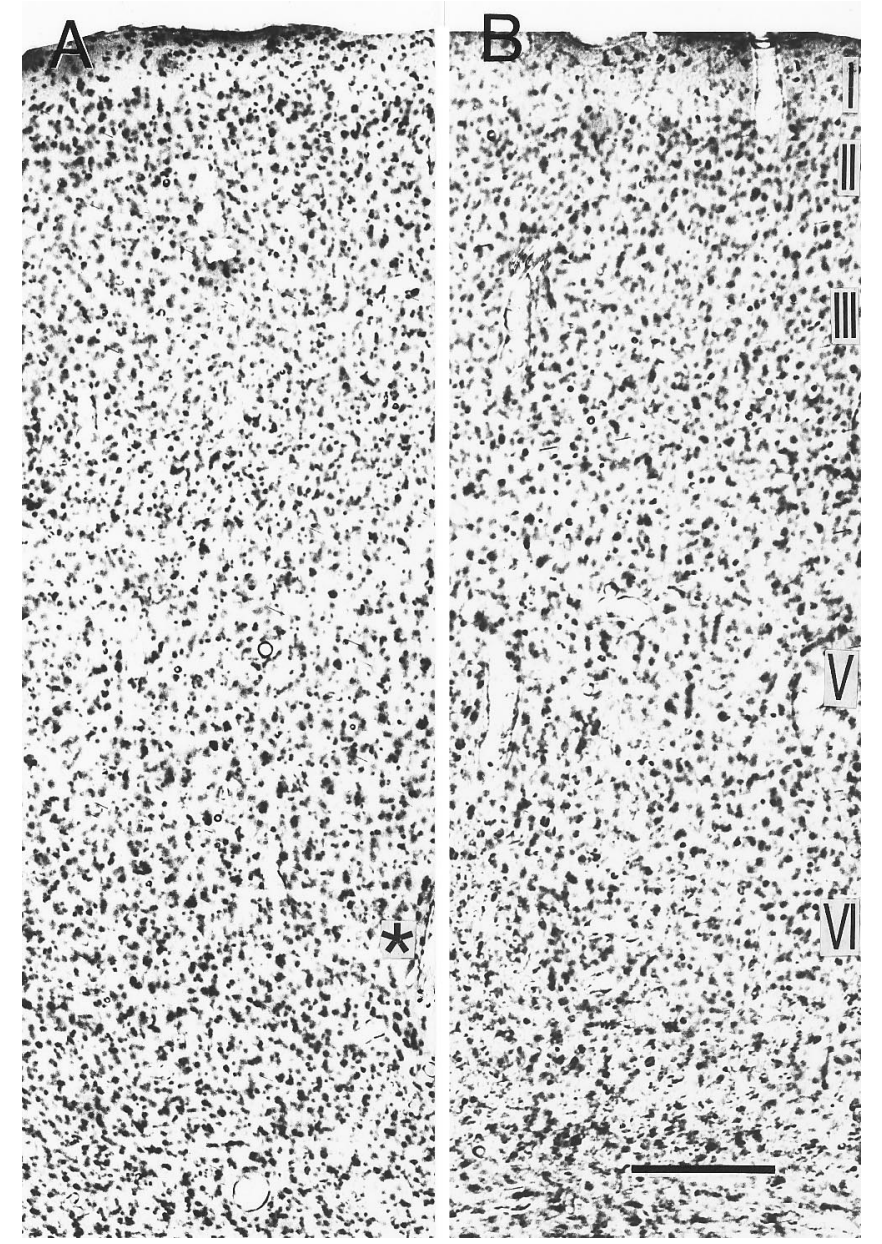

Figure 1. Photomicrographs showing thionin staining of the TT-injected motor cortex $(A)$ and the homotopic area on the contralateral side $(B)$. In thionin-stained sections, the TT-injected motor cortex showed no obvious cell loss or disturbance of cortical lamination, in comparison with the contralateral motor cortex or with control rats. The thionin-stained section shown here is adjacent to those shown in Figure $7 C, D$, in which marked decreases in GluR2 and increases in NR1 mRNA levels were seen in the TT-injected motor cortex. Asterisk indicates a blood vessel seen in Figure $7 C, D$. The rat received $35 \mathrm{ng}$ TT and was perfused $14 \mathrm{~d}$ later. Scale bar, $0.2 \mathrm{~mm}$.

$7 \mathrm{~d}$. Therefore, data from these two survival groups are described together. Three rats that were perfused $5 \mathrm{~d}$ and three that were perfused $7 \mathrm{~d}$ after injection showed downregulation of CaMKII $\alpha$ mRNA levels. All of these rats started demonstrating intermittent seizures 4 or more days after injection and 1-3 d before the perfusion. The areal extent of the downregulation varied. In two of the rats (one surviving $5 \mathrm{~d}$ and one surviving $7 \mathrm{~d}$ after injection), the decreases in CaMKII $\alpha$ mRNA levels involved almost all neocortical areas (with the exception of the retrosplenial cortex) on the side of TT injection, whereas in three others, the decreases were mainly in the frontoparietal cortex. The sixth rat that was perfused $7 \mathrm{~d}$ after TT injection showed downregulation of CaMKII $\alpha$ mRNA restricted to the motor cortex. The downregulation was most prominent in layers II-III but noticeable also in other layers (Fig. 3C). Densitometry analysis indicated on average a $24.98 \pm 12.88 \%$ (mean $\pm \mathrm{SD}$; range, $11.22-36.83 \%$ in individual rats; $n=6$ ) decrease in mRNA levels in the motor cortex (layers II-III) on the injected side, in comparison with that on the contralateral side (Fig. $4 A)$. The other four rats in the $5(n=1)$ 



Figure 2. Photomicrographs showing the normal patterns of in situ hybridization in the motor cortex for CaMKII $\alpha(A)$, CaMKII $\beta(B)$, GAD-67 (C), and NR1 mRNAs $(D)$. Cortical layers are indicated in $A$. Scale bar, $0.4 \mathrm{~mm}$.

or $7 \mathrm{~d}(n=3)$ survival group showed no clear changes in CaMKII $\alpha$ mRNA levels at the injection site. No seizure signs were observed in two of these rats (perfused on postoperative day 7). The other two (one at $5 \mathrm{~d}$ and one at $7 \mathrm{~d}$ ) were perfused $60 \mathrm{~min}$ after signs of seizures were first seen.

All seven rats that were perfused $14 \mathrm{~d}$ after TT injection had seizures beginning on postoperative days 5-13 and showed clear focal downregulation of CaMKII $\alpha$ mRNA at the injection site. At the focus, CaMKII $\alpha$ mRNA levels in layers III-V and upper layer VI were affected the most. Layer II did not show an obvious decrease (Fig. 3D,F). Quantitative analysis indicated an average decrease of $37.72 \pm 8.81 \%$ (range, $26.60-53.09 \% ; n=7$ ) in CaMKII $\alpha$ mRNA levels in layers III-VI at the focus, in comparison with the same layers of the homotopic area on the contralateral side (Fig. 4C). This decrease was statistically significant (Student's paired $t$ test, $p<$
$0.05)$. The areal extent of downregulation at the injection site ranged from 0.83 to $2.98 \mathrm{~mm}^{2}\left(1.88 \pm 0.72 \mathrm{~mm}^{2} ; n=7\right)$ as measured on sections through the center of the focus. One rat injected with $35 \mathrm{ng}$ TT had the largest areal extent of CaMKII $\alpha$ downregulation (2.98 $\mathrm{mm}^{2}$ ); the other rats that received $25 \mathrm{ng}$ TT showed considerable variation in the size of the focus $\left(0.83-2.27 \mathrm{~mm}^{2}\right)$. The focus was bordered by a zone of cortex displaying moderate upregulation of CaMKII $\alpha$ mRNA levels (Fig. 3D,F).

\section{CaMKII $\alpha$ expression in other brain regions}

Three of the rats injected with 25 or $35 \mathrm{ng}$ TT and perfused on postoperative day $7(n=1)$ or $14(n=2)$ also showed upregulation of $\mathrm{CaMKII} \alpha$ mRNA in the central lateral thalamic nucleus on the TT-injected side (Fig. $3 E$ ), but no changes in the ventral lateral thalamic nucleus were observed. The entorhinal cortex, hippocampal 

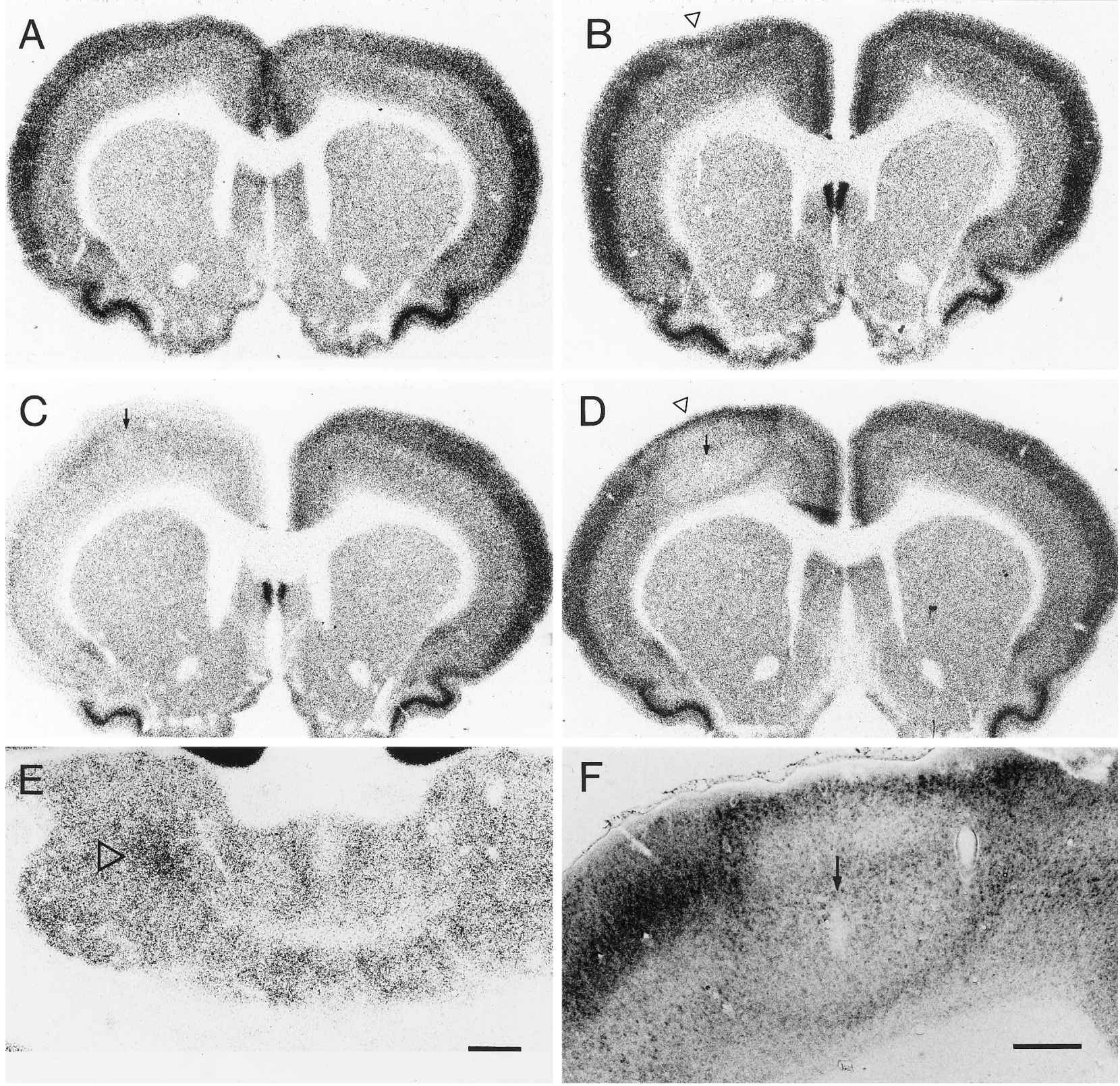

Figure 3. Photomicrographs showing in situ hybridization histochemistry for CaMKII $\alpha$ mRNA in control and TT-injected rat brains. $A$, In a saline-injected control rat, no obvious changes were seen in CaMKII $\alpha$ mRNA levels in the cerebral cortex. The rat was perfused $14 \mathrm{~d}$ after the injection. $B$, In a rat injected with $3 \mathrm{ng}$ TT and perfused $28 \mathrm{~d}$ after the injection, localized reductions in CaMKII $\alpha$ mRNA levels were observed at the injection site (open arrowhead), restricted mostly to cortical layers III-V. C, In a rat injected with $35 \mathrm{ng}$ TT and perfused $5 \mathrm{~d}$ later, most neocortical areas showed decreases in CaMKII $\alpha$ mRNA levels on the injected side (left). $D$, In a rat injected with $35 \mathrm{ng}$ TT and perfused $14 \mathrm{~d}$ later, CaMKII $\alpha$ mRNA levels were focally downregulated at the injection site (open arrowhead). This site was surrounded by a zone showing moderate upregulation of CaMKII $\alpha$ mRNA levels. $E$, CaMKII $\alpha$ mRNA levels were increased in the central lateral thalamic nucleus on the injected side (open arrowhead). $F$, Another example of focal CaMKII $\alpha$ downregulation at the injection site and upregulation in the surround similar to those shown in $D$. The rat received 25 ng TT and was perfused $14 \mathrm{~d}$ later. Arrows in $C, D$, and $F$ denote the injection site. Scale bars: $A-E$ (shown in $E$ ), $1 \mathrm{~mm} ; F, 0.4 \mathrm{~mm}$.

fields CA1-CA3, and the dentate gyrus also did not show obvious asymmetry of CaMKII $\alpha$ mRNA labeling between the two sides, nor did they exhibit differences from saline-injected or normal controls.

\section{CaMKII $\beta$ in situ hybridization}

CaMKII $\beta$ mRNA levels in the normal cerebral cortex were lower than those of CaMKII $\alpha$. Cortical layers II, III, V, and VI showed higher hybridization signal than layers I and IV or deep layer III (Fig. 2B). The pyramidal layer of the hippocampal fields CA1-
CA3, the granule cell layer of the dentate gyrus, and layer II of the piriform cortex exhibited higher levels of CaMKII $\beta$ mRNA than did other cortical layers or areas. Subcortical forebrain structures showing moderate hybridization for CaMKII $\beta$ mRNA included the septum, striatum, thalamus, and hypothalamus. The globus pallidus contained practically no $\mathrm{CaMKII} \beta$ hybridization signal.

CaMKII $\beta$ mRNA levels did not show a clear change in any of the TT-injected rats, in comparison with saline-injected or normal controls (Fig. $5 A$ ). 

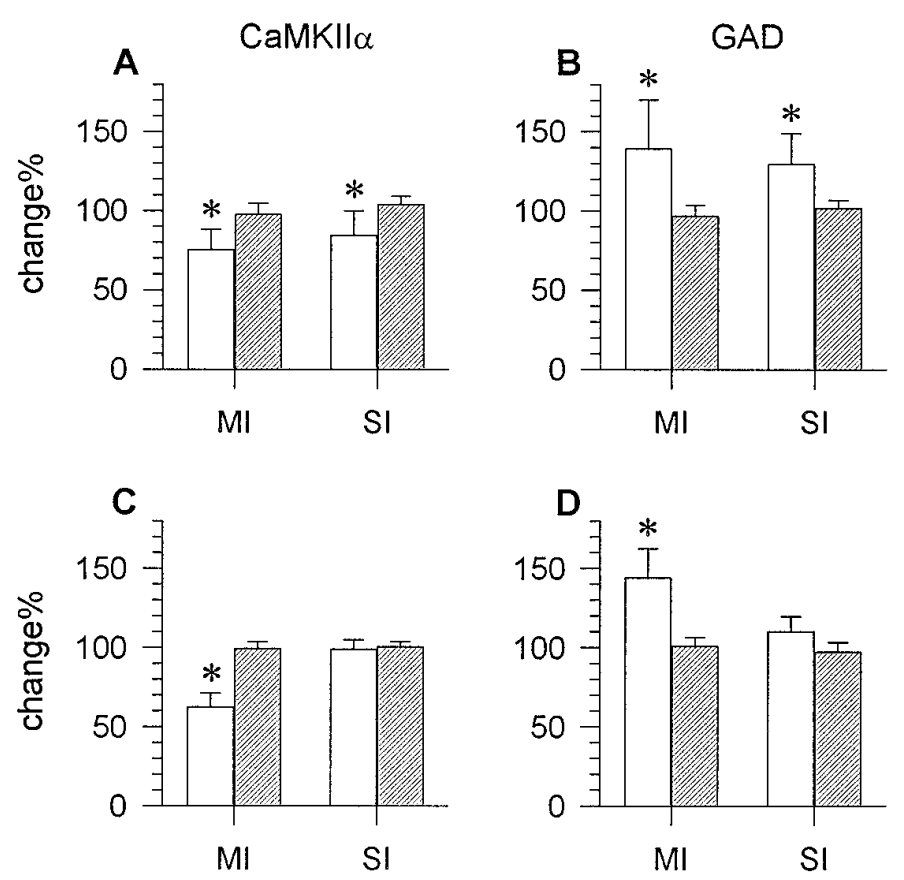

Cortical area

\section{Cortical area}

Figure 4. mRNA levels were significantly altered for CaMKII $\alpha(A, C)$ and $\operatorname{GAD}(B, D)$ in the epileptic rats (open bars) that survived for 5-7 $\mathrm{d}$ $(A, B)$ or $14 \mathrm{~d}(C, D)$ after the injection $(25-35 \mathrm{ng})$, whereas control rats (hatched bars) did not show significant differences in mRNA levels for either of the genes between homotopic areas on the two sides. The changes are expressed as percentage radioactivity (mean $\pm \mathrm{SD}$ ) in the motor $(M I)$ or first somatosensory $(S I)$ cortex on the TT-injected side relative to readings of radioactivity for the same cortical areas on the contralateral side. Each bar represents the average percentage value of six rats in the 5-7 d survival group, seven rats in the $14 \mathrm{~d}$ survival group, or three saline-injected control rats. ${ }^{*} p<0.05$ (Student's paired $t$ test).

\section{GAD in situ hybridization}

Normal pattern of hybridization

The pattern of GAD-67 mRNA hybridization in the rat brain has also been described previously (Benson et al., 1992; Liang et al., 1996). In the neocortex, GAD-67 mRNA-positive neurons were found in all layers, with moderately higher levels of hybridization signal in layers IV and VI (Figs. $2 C, 5 B$ ). No obvious asymmetry between the two hemispheres could be detected.

\section{Time-dependent up- and downregulation at the TT injection site and in the surround}

None of the rats injected with 2-13 ng TT in the pilot experiments showed detectable changes in GAD gene expression. For rats injected with larger doses of TT in the final experiments, changes in GAD-67 mRNA levels were opposite to those seen for CaMKII $\alpha$. The same six rats in the 5-7 d survival group, which showed decreases in CaMKII $\alpha$ mRMA levels, displayed upregulation of GAD-67 mRNA levels in the same neocortical areas on the injected side (Fig. 5C). The sensorimotor cortex on the injected side showed, on average, a $39.27 \pm 30.94 \%$ (range, 8.32$70.21 \% ; n=6$ ) increase in GAD-67 mRNA levels in layers III/IV, when compared with the contralateral side (Fig. 4B). The other rats in this survival group exhibited no clear changes in GAD-67 mRNA levels in the cortex. The same rats showed no changes in CaMKII $\alpha$ mRNA levels.

All rats in the 2 week survival group showed a focus of in-

creased GAD-67 mRNA levels at the TT injection site. Of all cortical layers, deep layer III (or IV) and layer VI showed the most prominent upregulation in the focus (Figs. $4 D, 5 D, 6 A$ ). The increases in deep layer III in the injected motor cortex ranged from $27.40 \%$ to $63.58 \%$, with a grand mean of $44.16 \% \pm 18.24 \%$ $(n=7)$, in comparison with the contralateral motor cortex (Fig. $4 D$ ). When compared with the contralateral first somatosensory cortex, GAD mRNA levels in the focus increased $30.45 \pm 12.74 \%$ (range, $19.08-52.24 \% ; n=7$ ) in layers III/IV. All of these changes were statistically significant (Student's paired $t$ test, $p<$ 0.05). The areal extent of GAD-67 upregulation at the injection site matched the area showing reduced CaMKII $\alpha$ mRNA levels in neighboring sections (Figs. $3 D, 5 D$ ). In emulsion-dipped sections, increases in GAD mRNA levels were manifested mainly by the higher density and larger areal extent of clusters of silver grains overlying GAD-positive neurons under dark-field illumination. There was no obvious increase in the number of GAD mRNApositive neurons in the TT-injected motor cortex (Fig. 6A).

In a zone surrounding the focus of GAD upregulation, GAD-67 mRNA levels were decreased by $16.86 \pm 10.24 \%$ in comparison with the contralateral motor cortex. Decreases in GAD-67 mRNA levels in the surround were more pronounced in layers II, III, and $\mathrm{V}$ (Figs. 5D, 6A).

The motor cortex on the contralateral side in some rats showed slight increases in GAD-67 mRNA levels in layer III. No significant changes in GAD-67 mRNA levels were found in other cortical or subcortical structures.

\section{GluR2 in situ hybridization Normal distribution}

In the neocortex, hybridization signal for GluR2 was very low in layer I, high in layers II, III, and V, moderate in layer IV, and intermediate in layer VI (Fig. $7 E$ ). The areal and laminar distribution of GluR2 mRNA was similar to that of NR1 mRNA (see below), but the overall levels of hybridization for GluR2 mRNA were much lower. The pyramidal layer of the hippocampal fields CA1-CA3, the granule cell layer of the dentate gyrus, layer II of the piriform cortex, and the retrosplenial cortex showed higher levels of GluR2 mRNA than did other areas.

\section{Time-dependent downregulation at the injection site}

For rats injected with larger doses of TT in the definitive experiments, those with seizures that survived for 5-7 d and showed decreases in CaMKII $\alpha$ mRNA and increases in GAD mRNA also demonstrated a decrease in GluR2 mRNA levels in the same neocortical areas on the TT-injected side (Figs. 7A, 8A). The decrease in the motor cortex was on average $36.59 \pm 8.29 \%$ (range, 27.28$47.11 \% ; n=6$ ) in layers V-VI. Those that did not show clear changes in $\mathrm{CaMKII} \alpha$ and GAD gene expression also did not give clear differences in GluR2 mRNA levels between the two sides.

Epileptic rats in the 2 week survival group showed a decrease in GluR2 mRNA levels at the injection site. The size of the focus of reduced GluR2 hybridization varied across animals and generally matched that of CaMKII $\alpha$ decrease and GAD-67 increase. Cortical layers III-VI were prominently affected. Layer II did not show obvious changes (Fig. 7C). GluR2 hybridization signal decreased by $23.36 \pm 19.64 \%$ (range, $5.14-38.39 \% ; n=7$ ) in layers $\mathrm{V}-\mathrm{VI}$ at the injection site in comparison with the contralateral motor cortex (Fig. $8 C$ ). These changes were statistically significant (Student's paired $t$ test, $p<0.05)$. Unlike CaMKII $\alpha$ or GAD mRNAs, GluR2 mRNA levels did not show clear changes in cortex around the focus. No 

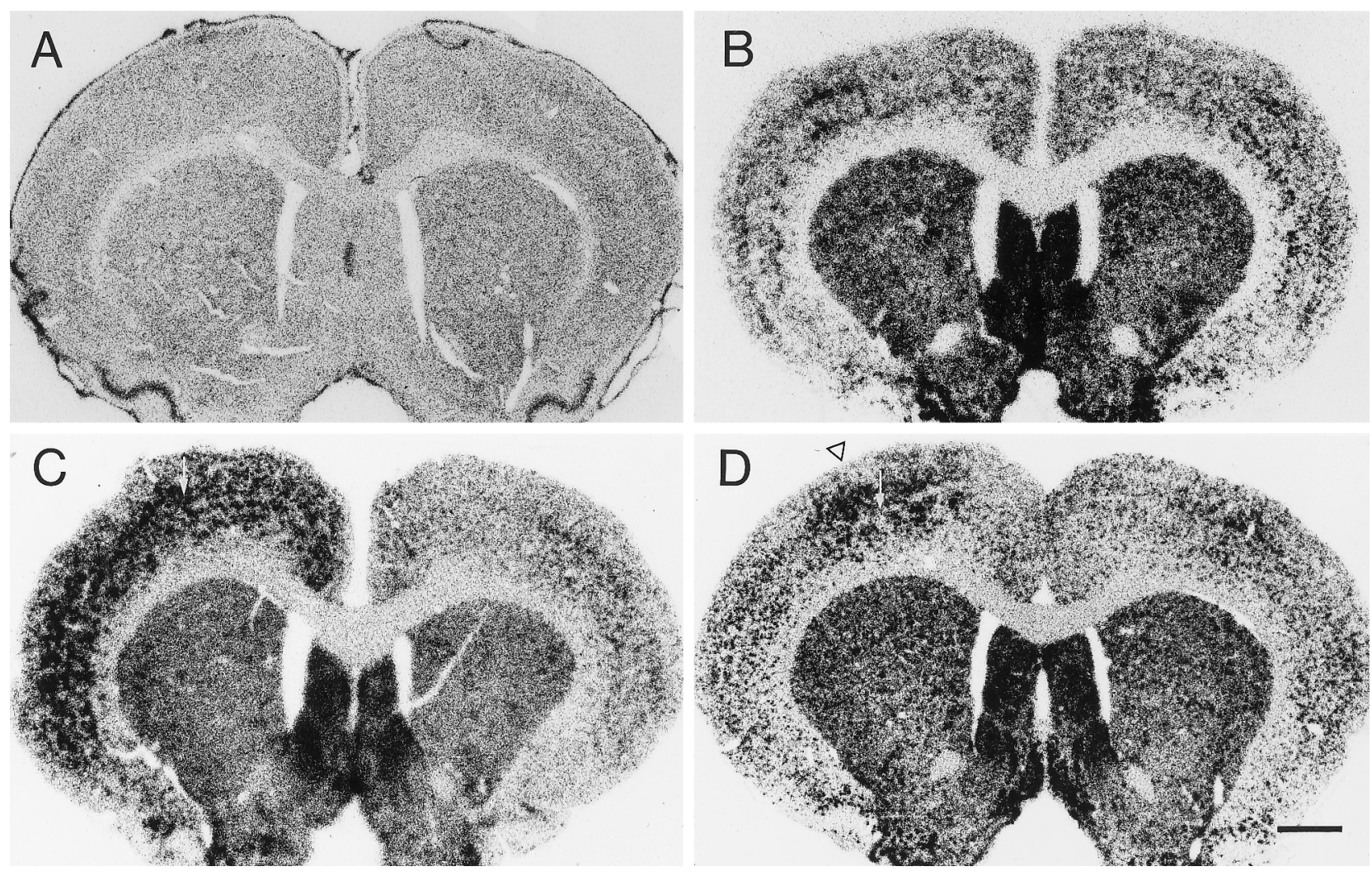

Figure 5. Photomicrographs showing CaMKII $\beta(A)$ and GAD-67 $(B-D)$ in situ hybridization histochemistry in rat brains injected with saline or TT. $A$, No changes were seen in CaMKII $\beta$ mRNA levels in a rat that was injected with $35 \mathrm{ng}$ TT in the left motor cortex and perfused $14 \mathrm{~d}$ later. $B$, GAD-67 in situ hybridization in a control rat injected with saline and perfused $14 \mathrm{~d}$ later. No significant changes were seen in GAD-67 mRNA levels on the injected side (left). $C$, In a rat injected with $35 \mathrm{ng}$ TT and perfused $7 \mathrm{~d}$ later, GAD-67 mRNA levels were significantly upregulated throughout most neocortical areas on the injected side $(l e f t) . D$, In a rat injected with $35 \mathrm{ng}$ TT and perfused $14 \mathrm{~d}$ later, GAD-67 mRNA levels were focally increased at the injection site in the motor cortex (open arrowhead). Note the decreased GAD-67 mRNA levels in the region surrounding the focus of GAD-67 upregulation. Arrows in $C$ and $D$ designate the injection site. Scale bar, $1 \mathrm{~mm}$.

obvious changes in GluR2 mRNA levels could be detected in other cortical areas or in subcortical structures.

\section{NR1 in situ hybridization}

\section{Normal pattern of hybridization}

NR1 mRNA levels in the cerebral cortex of normal control rats are generally high (Watanabe et al., 1993; Monyer et al., 1994), and this was confirmed. Among the layers of the neocortex, hybridization signal for NR1 was very low in layer I, high in layers II, III, and V, moderate in layer IV of the granular cortex or in deep layer III of the agranular cortex, and intermediate in layer VI. This pattern varied slightly among different cortical areas (Figs. $2 D, 7 F$ ). Subcortical structures such as the striatum, septum, thalamus, hypothalamus, and tectum and the pontine nuclei also showed moderate to intermediate levels of hybridization for NR1 antisense probe. The saline-injected controls exhibited no significant difference of NR1 labeling pattern from that of the normal controls.

\section{Time-dependent up- and downregulation at the TT injection site and in the surround}

For rats injected with larger doses of TT in the final experiments, all those in the 5-7 d survival group did not show detectable alterations in NR1 gene expression even though the same animals showed clear changes in CaMKII $\alpha$, GAD-67, and GluR2 mRNA levels (Figs. $7 B, 8 B$ ). In rats of the 2 week survival group, all of which had seizures, NR1 mRNA levels were focally increased at the TT injection site. The extent of this upregulation was similar to that of GAD-67 mRNA increase or CaMKII $\alpha$ mRNA decrease in the same animals. Cortical layers II and III showed the strongest increase in NR1 mRNA levels, but increases in other cortical layers were also discernible (Figs. 6B, 7D). NR1 mRNA levels at the injection site were up on average $45.52 \pm 25.46 \%$ (range, $21.34-96.11 \% ; n=7$ ) in layers II-III when compared with those in the contralateral motor cortex (Fig. 8D). When compared with the contralateral somatosensory cortex, the upregulation had a grand mean of $39.64 \pm 23.10 \%$, with a range of $14.53 \%-66.46 \%$ $(n=7)$. Compared with either the contralateral motor or first somatosensory area, the changes in the focus were statistically significant (Student's paired $t$ test, $p<0.05$ ).

NR1 mRNA levels in the zone surrounding the focus of upregulation were decreased. This zone of decreased NR1 mRNA levels extended for a greater distance in the superficial layers than in the deep layers (Figs. 6B, 7D).

The contralateral motor cortex showed a slight decrease of NR1 mRNA levels in some of the rats. No clear changes in NR1 mRNA levels were observed in other cortical and subcortical structures.

\section{DISCUSSION}

\section{Time-dependent changes in gene expression in TT-induced epilepsy}

Rats perfused 5-7 d after TT injection showed variable changes in gene expression related to the time of onset of seizures. Some showed no changes at all, because they had not developed seizures 

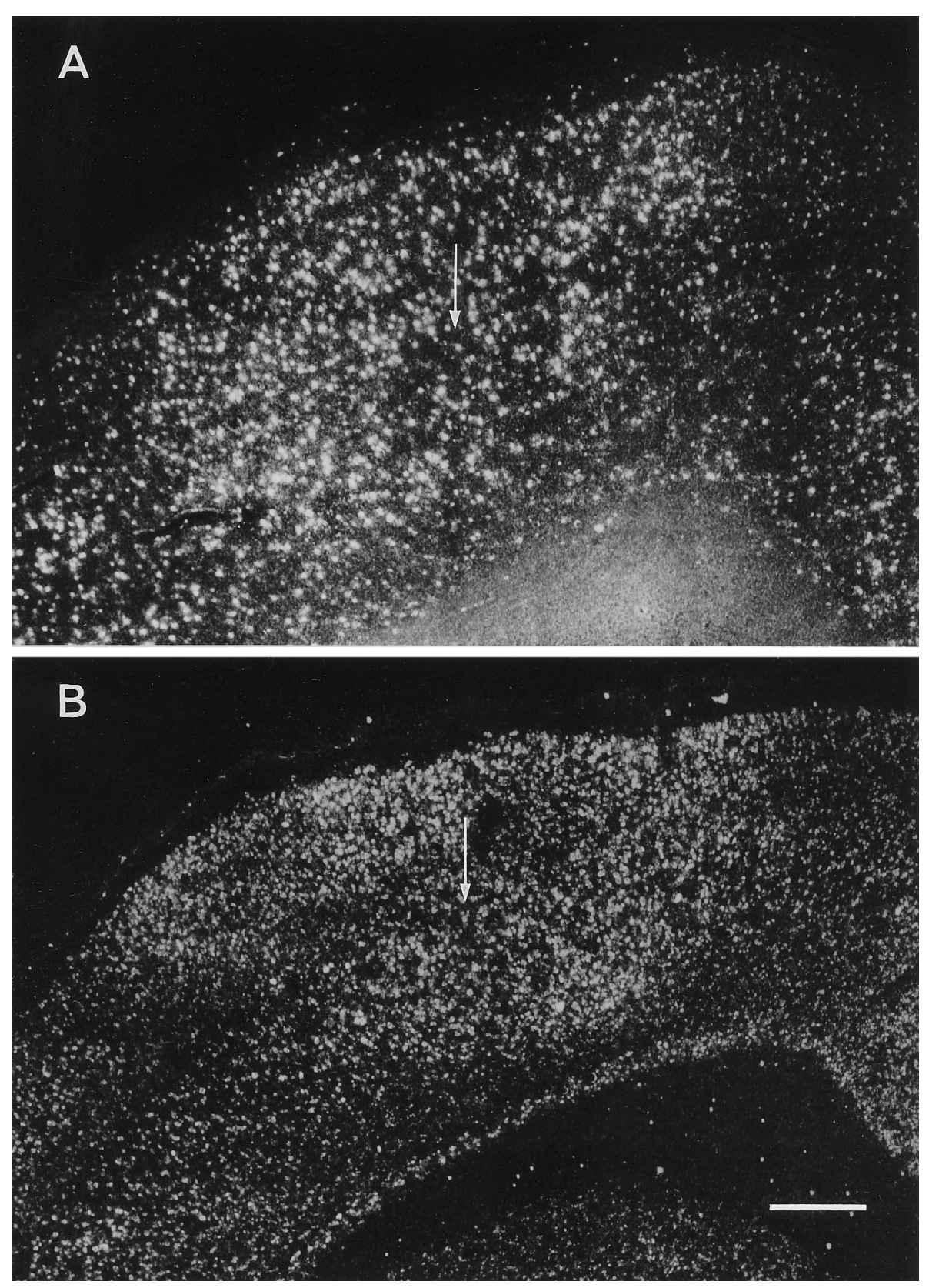

Figure 6. Dark-field photomicrographs from emulsion-autoradiographs showing the focal upregulation of $\operatorname{GAD}(A)$ and NR1 $(B)$ mRNA levels in the TT-injected motor cortex in rats that were perfused 2 weeks after injection of $35(A)$ or $25 \mathrm{ng}$ TT $(B)$. Note the downregulation of GAD and NR1 mRNA levels in a zone surrounding the focus of upregulation. Arrows indicate the injection site. Scale bar, $0.4 \mathrm{~mm}$. or had developed seizures just before perfusion. Others that had seizures showed altered gene expression of variable extent, ranging from changes in almost all neocortical areas on the injected side, through changes restricted to the frontoparietal cortex, to focal changes in the motor cortex at the injection site. Epileptic rats perfused $14 \mathrm{~d}$ after TT injection showed only focal changes in gene expression. These results suggest that in rats that developed seizures, changes in gene expression initially tended to be widespread on the injected side, likely resulting from spread of seizure activity, but the changes became delimited to restricted brain regions 2-3 d after seizure onset.

Variation among animals in the 5-7 d survival group are probably related to the variable latent period of 4-13 d between TT injection and the onset of behavioral seizures (present results; also see Mellanby et al., 1977; Louis et al., 1990). Some animals in this survival group were perfused before seizure development or very shortly after the first seizure and therefore showed no changes in the gene expression. Our observation that the earliest seizure signs were observed $4 \mathrm{~d}$ after TT injection support the assumption that seizure activity and altered gene expression are correlated, although abnormal neuronal discharges or evoked responses can be recorded in cerebral cortex $16 \mathrm{hr}$ after TT injection (Brener et al., 1990).

Changes in gene expression in five of the rats that survived for 5-7 d were characterized by widespread distribution in frontoparietal cortex (in three rats) or in almost all neocortical areas on the injected side (in two rats). This is probably related to the fact that TT-induced seizures were more severe and commonly more generalized in the first few days after onset, becoming more localized with time. At the beginning of seizure development, cortical protective mechanisms to prevent seizure activity from spreading may not have been engaged nor TT cleared from the brain. The conversion of a diffuse to a focal effect as shown in one rat that survived for $7 \mathrm{~d}$ and in all rats that survived for 2 weeks may 

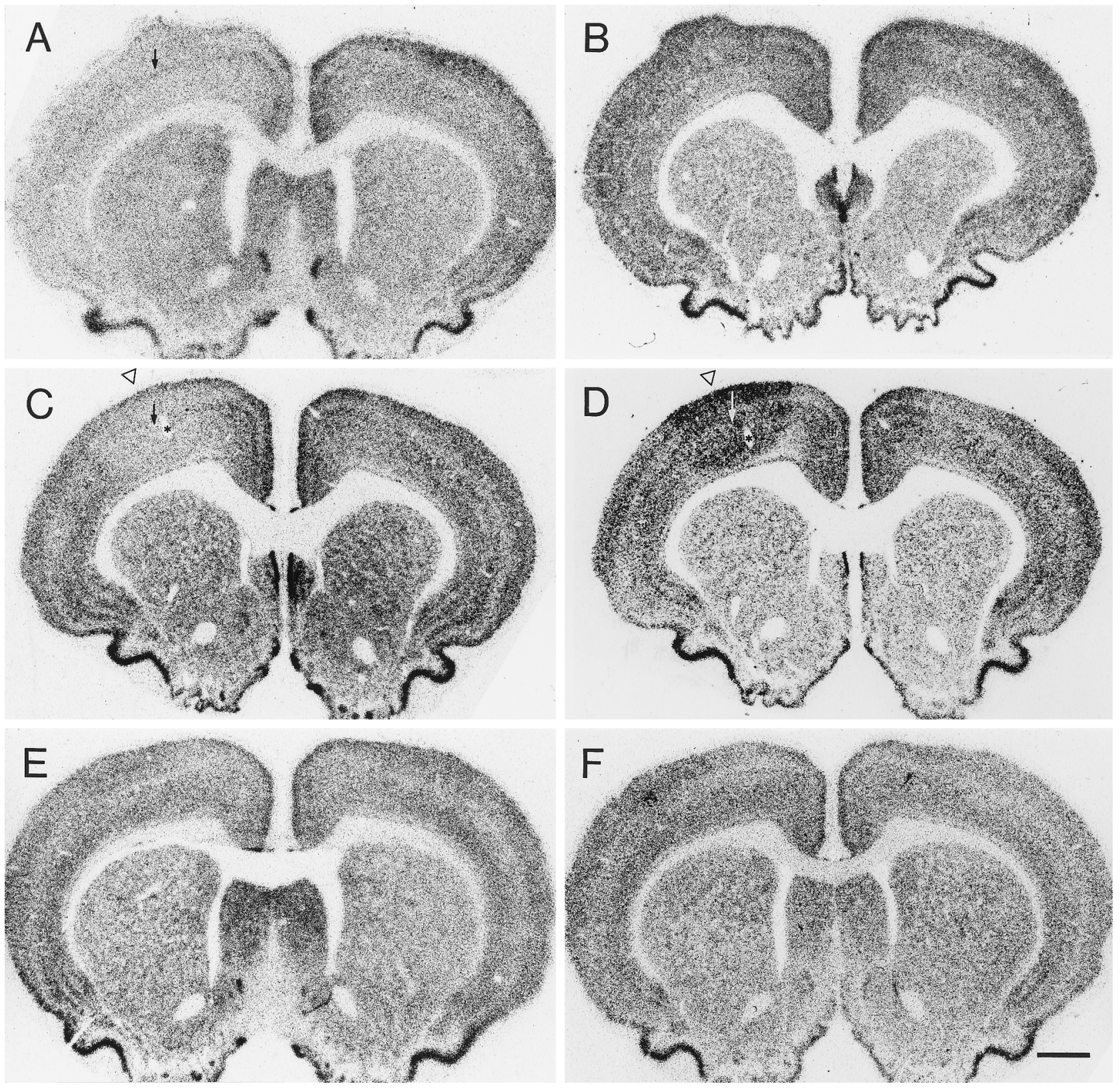

Figure 7. Photomicrographs showing in situ hybridization histochemistry for GluR2 (left) and NR1 (right) mRNAs in frontal sections at the level of the motor cortex. $A$, In a rat that was injected with $35 \mathrm{ng}$ TT and survived for $7 \mathrm{~d}$, GluR2 mRNA levels were decreased throughout most neocortical areas on the injected side (left), whereas NR1 mRNA levels $(B)$ were not clearly affected. $C$, In another rat that was injected with 35 ng TT and survived for $14 \mathrm{~d}$, GluR2 mRNA levels were downregulated focally at the injection site in the motor cortex (open arrowhead), and NR1 mRNA levels $(D)$ were focally upregulated at the injection site in the motor cortex (open arrowhead). Note the zone of NR1 mRNA downregulation around the focus of increased NR1 mRNA levels. $E$ and $F$ show that GluR2 and NR1 mRNA levels were not obviously changed in a saline-injected control rat. Arrows in $A, C$, and $D$ indicate the injection site. Asterisks in $C$ and $D$ indicate the same blood vessel marked in Figure $1 A$. Scale bar, $1 \mathrm{~mm}$.

indicate the engagement of counterepileptic mechanisms to constrain the spread of epileptic activity (see below). The gradual clearance of TT molecules from the brain may also contribute to the process of focalization.

It is unlikely that the changes in gene expression resulted from cell loss attributable to repetitive seizures. There is no detectable cell loss in TT-induced epilepsy (Kessler and Markowitsch, 1983; Jefferys et al., 1992), and none could be detected in the present study. In addition, upregulation of selective mRNAs is unlikely to occur in the presence of cell loss, although it is conceivable that death of a subpopulation of, e.g., GABA cells, could be compensated for by upregulation of GAD in remaining subpopulations.

Although changes in gene expression for $\mathrm{CaMKII} \alpha, \mathrm{GAD}$, NMDA, or AMPA receptor subunits have been reported in various animal models of epilepsy, such as kindling, status epilepticus, hippocampal hilus lesion, and genetically seizure-prone animals, the findings have been inconsistent (see introductory remarks). Most previous studies also describe bilateral and/or widespread changes in which secondary effects such as hypoxia, 

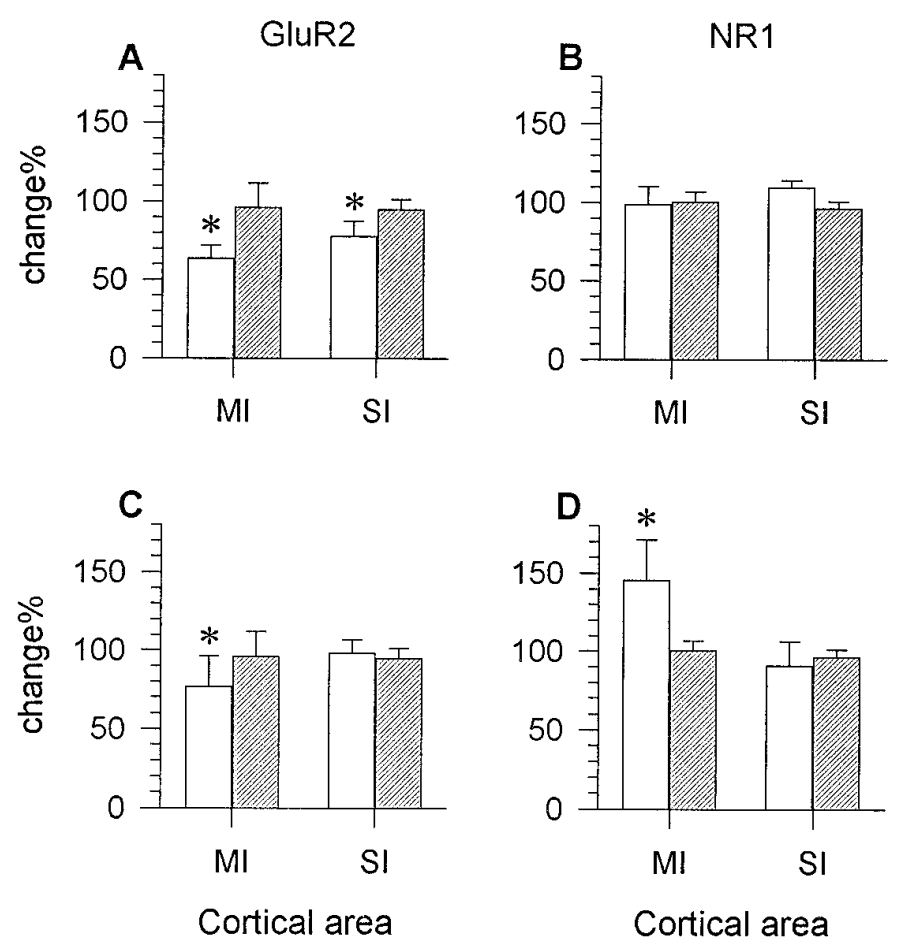

Figure 8. Bar graphs showing relative mRNA levels for $\operatorname{GluR} 2(A, C)$ and NR1 $(B, D)$ in the motor cortex $(M I)$ or first somatosensory cortex $(S I)$ of TT- (open bars) or saline-injected (hatched bars) rats. In epileptic rats perfused 5-7 d after the injection of TT (25-35 ng), GluR2 mRNA levels were significantly decreased in both MI and SI $(A)$. In the same epileptic rats, NR1 mRNA levels were not altered $(B)$. In epileptic rats perfused $14 \mathrm{~d}$ after TT injection (25-35 ng), significant downregulation of GluR2 $(C)$ and upregulation of NR1 mRNA levels $(D)$ were observed in MI but not in SI. There were no changes in MI or SI in saline-injected controls (hatched bars). The changes are expressed as percentage radioactivity (mean $\pm \mathrm{SD}$ ) on the TT- or saline-injected side relative to readings of radioactivity for the same cortical areas on the contralateral side. Each bar represents the average percentage value of six rats in the 5-7 d survival group, seven rats in the $14 \mathrm{~d}$ survival group, or three saline-injected control rats. ${ }^{*} p<0.05$ (Student's paired $t$ test).

stress, surgical lesion, or seizure-induced cell loss cannot be ruled out (Ballarín et al., 1991; Honkaniemi et al., 1995).

\section{TT, epileptic focus, and inhibitory surround}

Neurons in a TT-induced epileptic focus show many of the same discharge and membrane-potential characteristics as those in the penicillin model of focal epilepsy (Brener et al., 1990; Louis et al., 1990; Empson et al., 1993). Local cortical application of penicillin induces seizure activity by blocking the binding of GABA to $\mathrm{GABA}_{\mathrm{A}}$ receptors (Matsumoto and Ajmone-Marsan, 1964; Prince, 1968). Within the epileptic focus, the majority of neurons exhibits a typical paroxysmal depolarization shift followed by afterhyperpolarization (Prince and Wilder, 1967; Dichter and Spencer, 1969). By contrast, most neurons in the zone surrounding the epileptic focus show frequent, prolonged hyperpolarization. This zone has been termed the inhibitory surround (Prince and Wilder, 1967; Dichter and Spencer, 1969). Reduced activity in the inhibitory surround can be detected by 2-deoxyglucose mapping in the rat (Collins, 1978) and by optical imaging of stimulation-induced epileptiform activity in human cerebral cortex (Haglund et al., 1992).

The cortical zone showing changes in gene expression reciprocal to those at the center of the injection site in the present study likely corresponds to the inhibitory surround. The changes in gene expression in it are consistent with its being a zone of reduced neuronal activity. Hypoactivity induced by functional deafferentation upregulates CaMKII $\alpha$ and downregulates GAD mRNA or protein levels in the cerebral cortex (Hendry and Jones, 1986; Hendry and Kennedy, 1986; Benson et al., 1991a, 1994).

An alternative explanation of the reciprocal changes in the surround could be through the action of diffusible factors such as nitric oxide and carbon monoxide (Dawson and Snyder, 1994; Schuman and Madison, 1994), although the layer-specific changes in gene expression are difficult to explain on this basis.

\section{Molecular biological alterations in epilepsy}

The changes in gene expression, which are likely to be accompanied by corresponding changes in protein levels, imply long-term alteration in neuronal properties during TT-induced seizure generation and persistence. CaMKII $\alpha$ is enriched in the postsynaptic densities of excitatory synapses (Liu and Jones, 1996). Its proposed functions include modulating synthesis and release of neu-

\section{Normal condition}
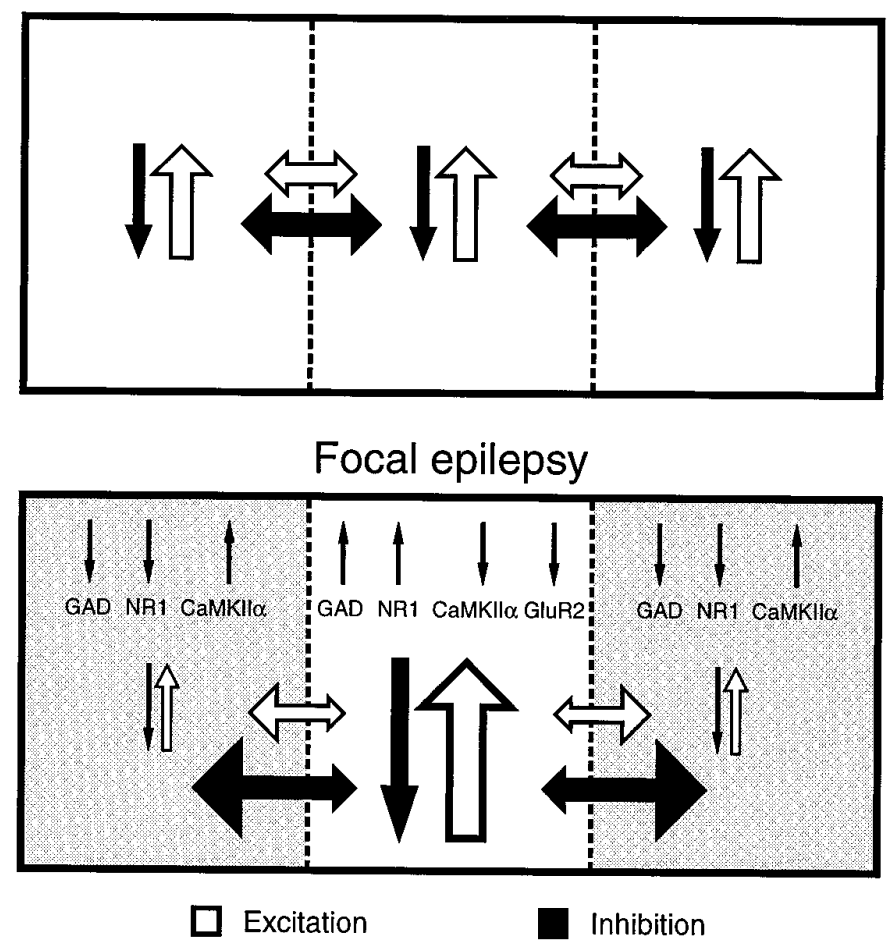

Figure 9. A schematic diagram illustrating excitatory and inhibitory interactions within and between columnar domains in the normal and focally epileptic cerebral cortex. In the normal cerebral cortex, horizontal and vertical streams of excitation and inhibition act in concert to restrict the magnitude and extent of spread of neural excitation (top), with horizontal spread limited by strong inhibitory circuits (Chagnac-Amitai and Connors, 1989). In the focally epileptic cerebral cortex (bottom), the epileptic focus exhibits enhanced excitation and inhibition, leading to activity-dependent upregulation of GAD and NR1 gene expression and downregulation of CaMKII $\alpha$ gene expression, but without changes in GluR2 gene expression. The reciprocal changes in the surrounding zone are thought to be caused by overwhelmingly increased lateral inhibition emanating from the focus. A resulting inhibitory surround would result in decreased lateral inhibition returning from the surround to the epileptic focus and should further facilitate epileptogenesis. Changes in transmitter, receptor, and protein kinase levels may then facilitate the persistence of hyperactivity and hyperexcitability in the epileptic focus, as seen experimentally in TT-induced epilepsy. 
rotransmitters, enhancing ion currents through glutamate receptors, mediating induction of long-term potentiation, and regulating gene transcription (Braun and Schulman, 1995). Downregulation of CaMKII $\alpha$ has been described in other models of epilepsy (Bronstein et al., 1992; Murray et al., 1995); however, in the present study the localized character of the decreases after 2 weeks contrasts with the widespread changes throughout bilateral neocortical and limbic structures reported in the other studies.

GAD gene expression is also activity-dependent (Benson et al., 1994). Any changes in the levels of GAD and therefore of GABA will affect the balance of excitation and inhibition in the cortex (Prince et al., 1992; Jones, 1993; Merlin and Wong, 1993). The present results suggest that GABA in the inhibitory synaptic terminals of axons originating from cells in the epileptic focus would be increased. In the initial period, GABA release within the injection focus should be blocked by TT; however, GABAergic terminals located outside the TT-effective focus but arising from axons of hyperactive GABAergic neurons inside the focus may exert increased inhibition, especially in the surround into which the long axons of the basket cells (Jones and Hendry, 1984; Kawaguchi, 1995), in particular, will extend. Increased inhibition in the presence of increased excitation has been suggested as playing a role in hypersynchronization of neuronal discharges in epilepsy (Fariello et al., 1991).

NMDA receptors, which gate $\mathrm{Ca}^{2+}$ influx, serve to modulate long-term neuronal excitability (Collingridge et al., 1988; Bliss and Collingridge, 1993), whereas GluR2 is the main subunit that limits $\mathrm{Ca}^{2+}$ permeability of the AMPA receptor channel (Hollmann et al., 1989; Boulter et al., 1990; Keinänen et al., 1990; Verdoorn et al., 1991; Burnashev, 1992). Therefore, the changes in NR1 and GluR2 expression demonstrated in the present study, although opposite in direction, together could cause elevated intracellular $\mathrm{Ca}^{2+}$ and also increase neuronal excitability in the epileptic focus. The reciprocal changes in gene expression in the surround could account for hypoexcitability in the inhibitory surround.

Unlike the other mRNAs investigated, NR1 mRNA did not show detectable changes in any TT-injected rats of the 5-7 d survival group. This may indicate that changes in NR1 gene expression may be related to the establishment of long-term changes rather than to immediate hyperexcitability. This could help establish a spontaneous epileptic focus beyond the immediate action of TT.

\section{Neurochemical segregation and a model of epileptogenesis}

The present study, in showing reciprocal changes in gene expression for several important molecules in an epileptic focus and its surround, suggests that the cortex in the epileptic focus is neurochemically isolated from the surround. Partial isolation of a cortical slab will cause development of epilepsy (Halpern, 1972; Hoffman et al., 1994). Neurochemical segregation of an epileptic focus from neighboring cortical areas without a structural disconnection may promote persistence of focal epilepsy even after the original cause of hyperactivity (TT in the present case) has been eliminated. One of the main constraints on lateral spread of activity in cortex is GABAergic inhibition (Chagnac-Amitai and Connors, 1989). Changes in GAD expression may provide a neurochemical substrate for the proposed functional disconnection of inhibitory neurons in epilepsy (Jefferys, 1994). Decreased activity in the surround and the associated downregulation of GAD expression could represent an attempt to restore the local balance of excitation and inhibition. This should result, however, in decreased lateral inhibition extending via basket cell axons from the surround to the epileptic focus; this in turn would be reinforced by the presumably strong lateral inhibition emanating from the hyperactive focus. Enhanced inhibition in the surround may serve to offset the increased excitation emanating from enhanced activity of horizontal collaterals of pyramidal cells in the hyperactive focus (Fig. 9).

Contributions by other cortical and subcortical structures, such as the central lateral thalamic nucleus, in the generation and maintenance of focal epilepsy should not be overlooked. These changes may alter properties of re-entrant connectional loops.

\section{REFERENCES}

Akbarian S, Sucher NJ, Bradley D, Tafazzoli A, Trinh D, Hetrick WP, Potkin SG, Sandman CA, Bunney Jr WE, Jones EG (1996) Selective alterations in gene expression for NMDA receptor subunits in prefrontal cortex of schizophrenics. J Neurosci 16:19-30.

Akiyama K, Yoneda Y, Ogita K, Itoh T, Daigen A, Sora I, Kohira I, Ujike H, Otsuki S (1992) Ionotropic excitatory amino acid receptors in discrete brain regions of kindled rats. Brain Res 587:73-82.

Asanuma H, Sakata H (1967) Functional organization of a cortical efferent system examined with focal depth stimulation in cats. J Neurophysiol 30:35-54.

Ballarín M, Ernfors P, Lindefors N, Persson H (1991) Hippocampal damage and kainic acid injection induce a rapid increase in mRNA for BDNF and NGF in the rat brain. Exp Neurol 114:35-43.

Bayer TA, Wiestler OD, Wolf HK (1995) Hippocampal loss of $N$-methylD-aspartate receptor subunit 1 mRNA in chronic temporal lobe epilepsy. Acta Neuropathol 89:446-450.

Benson DL, Isackson PJ, Gall CM, Jones EG (1991a) Differential effects of monocular deprivation on glutamic acid decarboxylase and type II calcium-calmodulin-dependent protein kinase gene expression in the adult monkey visual cortex. J Neurosci 11:31-47.

Benson DL, Isackson PJ, Hendry SH, Jones EG (1991b) Differential gene expression for glutamic acid decarboxylase and type II calciumcalmodulin-dependent protein kinase in basal ganglia, thalamus, and hypothalamus of the monkey. J Neurosci 11:1540-1564.

Benson DL, Isackson PJ, Gall CM, Jones EG (1992) Contrasting patterns in the localization of glutamic acid decarboxylase and $\mathrm{Ca}^{2+}$ calmodulin protein kinase gene expression in the rat central nervous system. Neuroscience 46:825-849.

Benson DL, Huntsman MM, Jones EG (1994) Activity-dependent changes in GAD and preprotachykinin mRNAs in visual cortex of adult monkeys. Cereb Cortex 4:40-51.

Bergey GK, Bigalke H, Nelson PG (1987) Differential effects of tetanus toxin on inhibitory and excitatory synaptic transmission in mammalian spinal cord neurons in culture: a presynaptic locus of action for tetanus toxin. J Neurophysiol 57:121-131.

Bliss TV, Collingridge GL (1993) A synaptic model of memory: longterm potentiation in the hippocampus. Nature 361:31-39.

Boulter J, Hollmann M, O'Shea-Greenfield A, Hartley M, Deneris E, Maron C, Heinemann S (1990) Molecular cloning and functional expression of glutamate receptor subunit genes. Science 249:1033-1037.

Braun AP, Schulman H (1995) The multifunctional calcium/calmodulindependent protein kinase: from form to function. Annu Rev Neurosci 57:417-445.

Brener K, Amitai Y, Jeffreys JGR, Gytnick MJ (1990) Chronic epileptic foci in neocortex: in vivo and in vitro effects of tetanus toxin. Eur J Neurosci 3:47-54.

Bronstein JM, Micevych P, Popper P, Huez G, Farber DB, Wasterlain CG (1992) Long-lasting decreases of type II calmodulin kinase expression in kindled rat brains. Brain Res 584:257-260.

Brooks VB, Asanuma H (1962) Action of tetanus toxin in the cerebral cortex. Science 137:674-676.

Burnashev N, Monyer H, Seeburg PH, Sakmann B (1992) Divalent ion permeability of AMPA receptor channels is dominated by the edited form of a single subunit. Neuron 8:189-198.

Carrea R, Lanari A (1962) Chronic effect of tetanus toxin applied locally to the cerebral cortex of the dog. Science 137:342-343.

Chagnac-Amitai Y, Connors BW (1989) Horizontal spread of synchronized activity in neocortex and its control by GABA-mediated inhibition. J Neurophysiol 61:747-758.

Collingridge GL, Thompson PA, Davies J, Mellanby J (1981) In vitro 
effect of tetanus toxin on GABA release from rat hippocampal slices. J Neurochem 37:1039-1041.

Collingridge GL, Herron CE, Lester RA (1988) Frequency-dependent $N$-methyl-D-aspartate receptor-mediated synaptic transmission in rat hippocampus. J Physiol (Lond) 399:301-312.

Collins RC (1978) Use of cortical circuits during focal penicillin seizures: an autoradiographic study with $\left[{ }^{14} \mathrm{C}\right]$ deoxyglucose. Brain Res 150:487-501.

Dawson TM, Snyder SH (1994) Gases as biological messengers: nitric oxide and carbon monoxide in the brain. J Neurosci 14:5147-5159.

DeFelipe J, Huntley GW, del Rio MR, Sola RG, Morrison JH (1994) Microzonal decreases in the immunostaining for non-NMDA ionotropic excitatory amino acid receptor subunits GluR 2/3 and GluR 5/6/7 in the human epileptogenic neocortex. Brain Res 657:150-158.

Dichter M, Spencer WA (1969) Penicillin-induced interictal discharges from the cat hippocampus. I. Characteristics and topographical features. J Neurophysiol 32:649-662.

Empson RM, Amitai Y, Jefferys JG, Gutnick MJ (1993) Injection of tetanus toxin into the neocortex elicits persistent epileptiform activity but only transient impairment of GABA release. Neuroscience 57:235-239

Fariello RG, Forchetti CM, Fisher RS (1991) GABAergic function in relation to seizure phenomena. In: Neurotransmitters and epilepsy (Fisher RS, Coyle JT, eds), pp 77-93. New York: Wiley-Liss.

Feldblum S, Ackermann RF, Tobin AJ (1990) Long-term increase of glutamate decarboxylase mRNA in a rat model of temporal lobe epilepsy. Neuron 5:361-371.

Francis PT, Lowe SL, Bowen DM, Jefferys JG (1990) Lack of change in neurochemical markers during the postepileptic phase of intrahippocampal tetanus toxin syndrome in rats. Epilepsia 31:697-701.

Friedman LK, Pellegrini-Giampietro DE, Sperber EF, Bennett MV, Moshe SL, Zukin RS (1994) Kainate-induced status epilepticus alters glutamate and $\mathrm{GABA}_{\mathrm{A}}$ receptor gene expression in adult rat hippocampus: an in situ hybridization study. J Neurosci 14:2697-2707.

Gall C, Sumikawa K, Lynch G (1990) Levels of mRNA for a putative kainate receptor are affected by seizures. Proc Natl Acad Sci USA 87:7643-7647.

Gerfin-Moser A, Grogg F, Rietschin L, Thompson SM, Streit P (1995) Alterations in glutamate but not $\mathrm{GABA}_{\mathrm{A}}$ receptor subunit expression as a consequence of epileptiform activity in vitro. Neuroscience 67:849-865.

Haglund MM, Ojemann GA, Hochman DW (1992) Optical imaging of epileptiform and functional activity in human cerebral cortex. Nature 358:668-671.

Hall RD, Lindholm EP (1974) Organization of motor and somatosensory neocortex in the albino rat. Brain Res 66:23-38.

Halpern LM (1972) Chronically isolated aggregates of mammalian cerebral cortical neurons studied in situ. In: Experimental models of epilepsy—a manual for the laboratory worker (Purpura DP, Penry JK, Tower DB, Walter RD, Woodbury DM, eds), pp 197-221. New York: Raven.

Hendry SH, Jones EG (1986) Reduction in number of immunostained GABAergic neurones in deprived-eye dominance columns of monkey area 17. Nature 320:750-753.

Hendry SH, Kennedy MB (1986) Immunoreactivity for a calmodulindependent protein kinase is selectively increased in macaque striate cortex after monocular deprivation. Proc Natl Acad Sci USA 83:1536-1541.

Hoffman SN, Salin PA, Prince DA (1994) Chronic neocortical epileptogenesis in vitro. J Neurophysiol 71:1762-1773.

Hollmann M, O'Shea-Greenfield A, Rogers SW, Heinemann S (1989) Cloning by functional expression of a member of the glutamate receptor family. Nature 342:643-648.

Honkaniemi J, Sagar SM, Pyykönen I, Hicks KJ, Sharp FR (1995) Focal brain injury induces multiple immediate early genes encoding zinc finger transcription factors. Mol Brain Res 28:157-163.

Jefferys JG (1994) Experimental neurobiology of epilepsies. Curr Opin Neurol 7:113-122.

Jefferys JGR, Evans BJ, Hughes SA, Williams SF (1992) Neuropathology of the chronic epileptic syndrome induced by intrahippocampal tetanus toxin in the rat: preservation of pyramidal cells and incidence of dark cells. Neuropathol Appl Neurobiol 18:53-70.

Jefferys JG, Borck C, Mellanby J (1995) Chronic focal epilepsy induced by intracerebral tetanus toxin. Ital J Neurol Sci 16:27-32.

Jones EG (1993) GABAergic neurons and their role in cortical plasticity in primates. Cereb Cortex 3:361-372.
Jones EG, Hendry SHC (1984) Basket cells. In: Cerebral cortex, vol 1, cellular components of the cerebral cortex (Peters A, Jones EG, eds), pp 309-336. New York: Plenum.

Jones EG, Huntley GW, Benson DL (1994) Alpha calcium/calmodulindependent protein kinase II selectively expressed in a subpopulation of excitatory neurons in monkey sensory-motor cortex: comparison with GAD-67 expression. J Neurosci 14:611-629.

Kamphuis W, De Rijk TC, Talamini LM, Lopes da Silva FH (1994) Rat hippocampal kindling induces changes in the glutamate receptor mRNA expression patterns in dentate granule neurons. Eur J Neurosci 6:1119-1127.

Kawaguchi Y (1995) Physiological subgroups of nonpyramidal cells with specific morphological characteristics in layer II/III of rat frontal cortex. J Neurosci 15:2638-2655.

Keinänen K, Wisden W, Sommer B, Werner P, Herb A, Verdoorn TA, Sakmann B, Seeburg PH (1990) A family of AMPA-selective glutamate receptors. Science 249:556-560.

Kessler J, Markowitsch HJ (1983) Different neuropathological effects of intrahippocampal injections of kainic acid and tetanus toxin. Experientia 39:922-924.

Kraus JE, Yeh GC, Bonhaus DW, Nadler JV, McNamara JO (1994) Kindling induces the long-lasting expression of a novel population of NMDA receptors in hippocampal region CA3. J Neurosci 14:4196-4205.

Lee S, Miskovsky J, Williamson J, Howells R, Devinsky O, Lothman E, Christakos S (1994) Changes in glutamate receptor and proenkephalin gene expression after kindled seizures. Mol Brain Res 24:34-42.

Lerner-Natoli M, Heaulme M, Leyris R, Biziere K, Rondouin G (1985) Absence of modifications in gamma-aminobutyric acid metabolism after repeated generalized seizures in amygdala-kindled rats. Neurosci Lett 62:271-276.

Liang F, Jones EG (1994) Neural plasticity induced by epileptiform activity of the rat motor cortex injected with tetanus toxin: mapping of CaM kinase II, GAD, $\mathrm{GABA}_{\mathrm{A}}$ receptor subunit mRNAs and $c$-fos immunoreactivity. Soc Neurosci Abstr 20:934.

Liang F, Jones EG (1996a) Reciprocal changes in gene expression for zif268 and NMDA receptor subunit NR1 in the epileptic focus and "inhibitory surround" induced by tetanus toxin in the motor cortex. Soc Neurosci Abstr 22:1439.

Liang F, Jones EG (1996b) Peripheral nerve stimulation increases Fos immunoreactivity without affecting CaM kinase II, GAD or GABA receptor gene expression in cat spinal cord. Exp Brain Res 111:326-336.

Liang F, Isackson PJ, Jones EG (1996) Stimulus-dependent, reciprocal up- and down-regulation of glutamic acid decarboxylase and $\mathrm{CaM}$ kinase II gene expression in rat cerebral cortex. Exp Brain Res 110:163-174.

Liu X-B, Jones EG (1996) Localization of alpha type II calcium calmodulin-dependent protein kinase at glutamatergic but not $\gamma$-aminobutyric acid (GABAergic) synapses in thalamus and cerebral cortex. Proc Natl Acad Sci USA 93:7332-7336.

Lopes da Silva KH, Kamphuis W, Titulaer M, Vreugdenhil M, Wadman WJ (1995) An experimental model of progressive epilepsy: the development of kindling of the hippocampus of the rat. Ital J Neurol Sci 16:45-57.

Louis ED, Williamson PD, Darcey TM (1990) Chronic focal epilepsy induced by microinjection of tetanus toxin into the cat motor cortex. Electroencephalogr Clin Neurophysiol 75:548-557.

Marianowski R, Pollard H, Moreau J, Despres G, Ben Ari Y, Tran Ba Huy P, Romand R (1995) $N$-methyl-D-aspartate receptor subunits NR1 and NR2C are overexpressed in the inferior colliculus of audiogenic mice. Neurosci Lett 189:190-194.

Matsumoto H, Ajmone-Marsan C (1964) Cortical cellular phenomena in experimental epilepsy: interictal manifestations. Exp Neurol 9:286-304.

Meldrum BS (1994) The role of glutamate in epilepsy and other CNS disorders. Neurology 44:S14-23.

Mellanby J, George G, Robinson A, Thompson P (1977) Epileptiform syndrome in rats produced by injecting tetanus toxin into the hippocampus. J Neurol Neurosurg Psychiatry 40:404-414.

Merlin LR, Wong RK (1993) Synaptic modifications accompanying epileptogenesis in vitro: long-term depression of GABA-mediated inhibition. Brain Res 627:330-340.

Mitsuyoshi I, Ito M, Shirasaka Y, Mikawa H, Serikawa T, Yamada J (1993) Changes of NMDA receptor binding in spontaneously epileptic rat and parent strains. Neurochem Res 18:1169-1173.

Monyer H, Burnashev N, Laurie DJ, Sakmann B, Seeburg PH (1994) 
Developmental and regional expression in the rat brain and functional properties of four NMDA receptors. Neuron 12:529-540.

Murray KD, Gall CM, Benson DL, Jones EG, Isackson PJ (1995) Decreased expression of the alpha subunit of $\mathrm{Ca}^{2+} /$ calmodulin-dependent protein kinase type II mRNA in the adult rat CNS following recurrent limbic seizures. Mol Brain Res 32:221-232.

Najlerahim A, Williams SF, Pearson RCA, Jefferys JGR (1992) Increased expression of GAD mRNA during the chronic epileptic syndrome due to intrahippocampal tetanus toxin. Exp Brain Res 90:332-342.

Neafsey EJ, Bold EL, Haas G, Hurley-Gius KM, Quirk G, Sievert CF, Terreberry RR (1986) The organization of the rat motor cortex: a microstimulation mapping study. Brain Res Rev 11:77-96.

Obenaus A, Esclapez M, Houser CR (1993) Loss of glutamate decarboxylase mRNA-containing neurons in the rat dentate gyrus following pilocarpine-induced seizures. J Neurosci 13:4470-4485.

Pollard H, Heron A, Moreau J, Ben-Ari Y, Khrestchatisky M (1993) Alterations of the GluR-B AMPA receptor subunit flip/flop expression in kainate-induced epilepsy and ischemia. Neuroscience 57:545-554.

Prince DA (1968) The depolarization shift in "epileptic" neurons. Exp Neurol 21:467-485.

Prince DA, Wilder BJ (1967) Control mechanisms in cortical epileptogenic foci: "surround" inhibition. Arch Neurol 16:194-202.

Prince DA, Deisz RA, Thompson SM, Chagnac-Amitai Y (1992) Functional alterations in GABAergic inhibition during activity. Epilepsy Res (Suppl) 8:31-38.

Prince HK, Conn PJ, Blackstone CD, Huganir RL, Levey AI (1995)
Down-regulation of AMPA receptor subunit GluR2 in amygdaloid kindling. J Neurochem 64:462-465.

Racine RJ (1972) Modification of seizure activity by electrical stimulation. II. Motor seizure. Electroencephalogr Clin Neurophysiol 32:281-294.

Ribak CE, Harris AB, Vaughn JE, Roberts E (1979) Inhibitory, GABAergic nerve terminals decrease at sites of focal epilepsy. Science 205:211-214.

Schiavo G, Benfenati F, Poulain B, Rossetto O, Polverino de Laureto P, DasGupta BR, Montecucco C (1992) Tetanus and botulinum-B neurotoxins block neurotransmitter release by proteolytic cleavage of synaptobrevin [see comments]. Nature 359:832-835.

Schuman EM, Madison DV (1994) Nitric oxide and synaptic function. Annu Rev Neurosci 17:153-183.

Sugihara H, Moriyoshi K, Ishii T, Masu M, Nakanishi S (1992) Structures and properties of seven isoforms of the NMDA receptor generated by alternative splicing. Biochem Biophys Res Commun 185:826-832.

Verdoorn TA, Burnashev N, Monyer H, Seeburg PH, Sakmann B (1991) Structural determinants of ion flow through recombinant glutamate receptor channels. Science 252:1715-1718.

Watanabe M, Inoue Y, Sakimura K, Mishina M (1993) Distinct distributions of five $N$-methyl-D-aspartate receptor channel subunit mRNAs in the forebrain. J Comp Neurol 338:377-390.

Williamson LC, Fitzgerald SC, Neale EA (1992) Differential effects of tetanus toxin on inhibitory and excitatory neurotransmitter release from mammalian spinal cord cells in culture. J Neurochem 59:2148-2157. 